\title{
INTERNATIONAL ASSISTANCE AND \\ COOPERATION IN HEALTH UNDER THE \\ INTERNATIONAL LAW REGIME: A CALL FOR \\ RESPONSIBILITIES
}

\author{
COOPERACIÓN Y ASISTENCLA INTERNACIONAL \\ EN SALUD EN EL REGIMEN DE DERECHO \\ INTERNACIONAL: UNA LLAMADA A LAS \\ RESPONSABILIDADES
}

Angela Pires Terto

angelapiresp@gmail.com

Recebido em 04/08/2013

Aprovado em 15/10/2013

1.Introduction, 2. International legal foundations, 3. Extra-territorial responsibility, 4. Responsibilities to seek and provide IAC, 5. Obligations to respect, protect and fulfil, 6. Core principles, 6.1. Non-discrimination and equality, 6.2. Interdependence, 6.3. Participation, 6.4. Transparency, 6.5. Monitoring and Accountability, 6.6. Coherence and Coordination, 7. Conclusions, 8. Bibliography

Abstract

This article examines the international assistance and cooperation (LAC) under the international law. It discusses buman rights obligations regarding IAC in bealth taking into account international legal foundations and drawing core principles based in the right to bealth normative features. It also suggests that extra-territorial responsibilities should apply in order to prevent human rights violations in the context of IAC.

Keywords

International cooperation, extra-territorial responsibility, buman rights, state's obligations.
Resumen

El artículo analisa la cooperación y asistencia internacional (IAC, en inglés) a partir del derecho internacional. Discute las obligaciones de derechos bumanos sobre IAC en salud tomando en cuenta los marcos legales y diseñando los principios centrales con base en los elementos normativos del derecho a salud. También sugiere que las responsabilidades extraterritoriales debrian aplicarse para prevenir violaciones de los derechos bumanos en el context de la IAC.

Palabras llave:

Cooperación international, responsabilidad extraterritorial, derechos bumanos, obligaciones estatales. 


\section{Introduction}

International Assistance and Cooperation (IAC) is an old practice among states. In the aftermath of World War II, the need to target developing countries and those affected by armed conflicts had been strengthened. In 1944, the Bretton Woods Conference institutionalized the first policies on technical cooperation. However, after more than sixty years of donor-dictated ${ }^{1}$ practices, the approaches to IAC in health have attracted criticisms. For instance, in 2008, a workshop conducted by the University of Oxford's Global Economic Governance Programme gathered Ministers and other high level authorities on health from developing countries to discuss their states' agenda for global health (GEGP, 2008, P.2). One issue that arose from the discussions was how IAC was contributing to weaken national responses instead of promoting ownership and development. The traditional imposition of donors' own agendas and means of implementing, evaluating and monitoring was said to be undermining the 'recipient' country own needs and perspectives. In the words of one of the participants of the aforementioned workshop: "We [developing countries] want to work with them [the donors] not to be told what to do by them" (GEGP, 2008, P.2).

It is well accepted that countries should engage in IAC. This is one of the purposes of the United Nations ${ }^{2}$, the Organisation of American States ${ }^{3}$, the African Union ${ }^{4}$ and other coalitions of countries. However, there is considerably less agreement as to the IAC's precise nature.

Many authors discuss IAC as a political relationship. For Axelrod and Keohane (1985, P. 253), for instance, IAC is a political relationship that "can be designed to help a few at the expense of the rest", based on games of bargaining. Other authors believe that IAC is solely based on international agreements and solidarity. On the other hand, Skogly (2006), Salomon (2010), Mesquita, Hunt and Khosla (2010) draw our attention to several international instruments, including human rights treaties, which impose obligations on states that include IAC in their provisions. Regarding the IAC in health, Mesquita, Hunt and Khosla (2010, P.105) define it as a human rights responsibility. While exploring the conceptual framework on economic, social and cultural rights, the authors stress the human rights obligations established by

1 Also known as 'top-down' practices, these initiatives lack dialogue in considering the beneficiaries' real needs. They also can be characterised by imposing conditions for their implementation that, not rarely, have the potential to undermine part of the efforts to reach their aims.

2 Article 1(3) of the United Nations Charter establishes, as one of its purposes: "To achieve international co-operation in solving international problems of an economic, social, cultural, or humanitarian character, and in promoting(...)". In addition, its chapter IX addresses international economic and social cooperation.

3 Article 2(f) of the OAS Charter establishes as one of its purposes: "To promote, by cooperative action, their economic, social, and cultural development".

4 Article 2(1)(e) of the African Union Charter establishes as one of its purposes: "To promote international cooperation, having due regard to the Charter of the United Nations and the Universal Declaration of Human Rights". 
several treaties, including "soft law" instruments. In this way, this article explores the relationship between IAC and the right to health. While bringing arguments that sustain the existence of human rights obligations within IAC initiatives, it will focus on the obligations related to the right to health.

\title{
2. International legal foundations
}

At the global system for the protection of human rights, the Universal Declaration on Human Rights (1948), the ICESCR - International Covenant on Economic, Social and Cultural Rights (1976), the Convention on the Rights of the Child (1990), the Convention on the Rights of Persons with Disabilities (2006) and the International Convention for the Protection of All Persons from Enforced Disappearance (2010) provide additional provisions concerning States' responsibility on IAC.

Under ICESCR, the formulation of the right to health provided by article 12 reads in conjunction with article $2(1)$, which determines the State's obligations "to take steps, individually and through international assistance and cooperation, especially economic and technical". Also, in its General Comment 3, the Committee on the Economic, Social and Cultural Rights emphasizes that:

\begin{abstract}
in accordance with Articles 55 and 56 of the Charter of the United Nations, with well-established principles of international law, and with the provisions of the Covenant itself, international cooperation for development and thus for the realization of economic, social and cultural rights is an obligation of all States (CESCR, 1991, Para.14. Emphasis added).
\end{abstract}

Similarly, under the Convention on the Rights of the Child, the obligation related to IAC is placed in the core articles of the instrument. Therefore, article 4 on the general obligations provides that "with regard to economic, social and cultural rights, States Parties shall undertake such measures to the maximum extent of their available resources and, where needed, within the framework of international co-operation" (emphasis added). Further, article 24(4), especially regarding the right to health, provides as follows:

\footnotetext{
States Parties undertake to promote and encourage international cooperation with a view to achieving progressively the full realization of the right recognized in the present article. In this regard, particular account shall be taken of the needs of developing countries.
}

The Convention on the Rights of Persons with Disabilities also addresses the obligation of IAC in article 4(2). Further, article 32 explicitly addresses international cooperation, placing some necessary measures concerning the rights of persons with disabilities. Similarly, the International Convention for the Protection of All 
Persons from Enforced Disappearance in its article 15 is explicit to establish that states should cooperate with each other to assist victims of enforced disappearances.

Despite their non-binding nature, other instruments can also be used to guide interpretation and implementation of binding provisions. In 1978, the Alma-Ata Declaration (1994) stated the importance of IAC in tackling the barriers for the realisation of the right to health. It was followed by other several declarations, including the Declaration on the Right to Development (1986), the Vienna Declaration and Programme of Action (1993), the Cairo Declaration on Population \& Development (1994), the Copenhagen Declaration (1995) and the Oslo Declaration "Foreign Policy and Global Health Initiative" (2007), which are also examples of states' commitment to strengthen and intensify IAC. It is well accepted that the Declaration on the Right to Development and other related instruments have particular importance to IAC in health (MESQUITA, ET AL, 2010, P.110111). While regarding development, as "the constant improvement of the well-being of the entire population and of all individuals" (Preamble, Para.2), the declaration stresses the state's "duty to co-operate with each other in ensuring development and eliminating obstacles to development" (Art. 3(3)) $)^{5}$. Moreover, Salomon claims that the right to development is conditioned by IAC (2010, P.128), emphasising the importance of IAC's initiatives.

In the context of HIV, several non-binding instruments emphasize the state's responsibility towards IAC. For instance, in 2000 the Millennium Declaration was explicit on including the combat to HIV/AIDS ${ }^{6}$ and the states' responsibility to strengthen and intensify IAC. The declaration also places the following as fundamental values to international relations: freedom, equality, solidarity, tolerance, respect for nature and shared responsibility (UN, 2000, Para.6).

Further, in 2001, the UN Declaration of Commitment on HIV/AIDS (hereinafter UNGASS Declaration) urged for the intensification of regional, subregional and interregional cooperation and the strengthening of international and regional cooperation (UNGASS, 2001, Paras.27;73). Other UN resolutions also follow the same arguments. At the regional level, similar initiatives seek to strengthen IAC in order to promote the right to health. For instance, in the InterAmerican system, the 'Protocol of San Salvador' (1992) on economic, social and cultural rights, article 10 (right to health) read in conjunction to article 1 (obligation to adopt measures) requires that states "undertake to adopt the necessary measures, both domestically and through international cooperation". In addition, the Inter-

\footnotetext{
Also in Article 4. "1. States have the duty to take steps, individually and collectively, to formulate international development policies with a view to facilitating the full realization of the right to development. 2. Sustained action is required to promote more rapid development of developing countries. As a complement to the efforts of developing countries, effective international co-operation is essential in providing these countries with appropriate means and facilities to foster their comprehensive development."

Later it was regarded as the Millennium Development Goal n. ${ }^{\circ} 6$.
} 
American Convention on the Prevention, Punishment and Eradication of Violence Against Women (Convention of Belem do Para) and the Inter-American Convention on the Forced Disappearance of Persons also contain the state's responsibility towards IAC. In the African system for the protection of human rights, there is no mention to state's responsibility on $\mathrm{IAC}^{7}$. However, most of African states are parties to the mentioned UN human rights treaties ${ }^{8}$, even though the African Charter on Human and Peoples' Rights is the only binding document that explicitly addresses the right to development.

\section{Extra-territorial responsibility}

From the aforementioned international human rights instruments, it could be argued that there is a legal obligation to IAC in health. Skogly also stresses that the soft-law instruments offer a significant contribution to clarify the content of states obligations related to IAC (2006, P.143). Thus, considering the State's responsibilities under the international human rights law, it is necessary to determine whether these obligations are applicable outside its territory. This discussion gains particular importance when a state engages in IAC in another country.

Salomon (2010, P.135) and Skogly (2006) draw our attention to the evolving jurisprudence on civil and political rights that recognises the state's responsibilities outside its territory. For instance, the Human Rights Committee understands the application of the Covenant to be within the state's territory or jurisdiction regardless of location but depending on the 'power or effective control' that the State Party exercises outside its territory (HRC, 2004, Para.10). On the other hand, Skogly emphasizes that the international courts and the Inter-American Commission on Human Rights 'have not had a systematic or a consistent practice' (2006, P.165) on determining extra-territorial obligations. For instance, while the European Court of Human Rights in Loizidou v. Turkey (ECHR, 1996, Paras.58-64) recognized the state's responsibility in regard to the effects produced outside its own territory, in Bankovic v. Belgium (2001) responsibility with its territory. According to Skogly, "by dismissing that there was a jurisdictional link between the people in the radio tower and the contracting parties members of NATO, the Court effectively dismissed the protection of the law by the application of jurisdiction by any state"(SKOGLY, 2006, P.181-182).

\footnotetext{
Indeed, the only mention on international assistance is in regard to self-determination of peoples and the responsibility of member states to assist them 'in their liberation struggle against foreign domination, be it political, economic or cultural' at the African Charter on Human and Peoples' Rights, article 20(3).

8 On October 2013, from African states, only Somalia was not party to CRC, and Sao Tome and Principe, and South Africa have not ratified ICESCR.

9 The complaint regards the loss of lives during a NATO bombing to a radio and television station in Belgrade in 1999.
} 
Indeed, while the European jurisprudence still lacks uniformity in regard to this issue, the Inter-American Commission of Human Rights has taken the view that states have human rights obligations beyond their territory. For instance, in Coard et. al. v. United States, a case similar to Bankovic v. Belgium, the Commission found the following concerning state's obligations:

\begin{abstract}
under certain circumstances, the exercise of its jurisdiction over acts with an extraterritorial locus will not only be consistent with but required by the norms which pertain... Given that individual rights inhere simply by virtue of a person's humanity, each American State is obliged to uphold the protected rights of any person subject to its jurisdiction. While this most commonly refers to persons within a state's territory, it may, under given circumstances, refer to conduct with an extraterritorial locus where the person concerned is present in the territory of one state, but subject to the control of another state - usually through the acts of the latter's agents abroad. In principle, the inquiry turns not on the presumed victim's nationality or presence within a particular geographic area, but on whether, under the specific circumstances, the State observed the rights of a person subject to its authority and control (IACHR, 1999, Para.37).
\end{abstract}

The African system for the protection of human rights had the opportunity to address this issue in Democratic Republic of the Congo v Burundi, Rwanda and Uganda (ACHPR, 2003). In this first inter-state communication submitted to the African Commission on Human and Peoples' Rights in regard of violence against civilians and illegal exploitation of national resources by the troops of Burundi, Rwanda and Uganda, the African Commission understood that the respondent states should provide adequate reparations to and on behalf of victims "while [their] armed forces ... were in effective control of the provinces of the complainant state, which suffered these violations" (BANKOVIC V. BELGIUM ET AL).

Although Gomez Isa (SD) considers that the discussion under the perspective of economic, social and cultural rights has not received much attention so far, the aforementioned international human rights instruments can provide the basis for extra-territorial obligations related to this category of rights. Maintaining this perspective, Skogly argues that, for instance, from the General Comments of the CESCR, there is "no doubt that states are under legal obligations to ensure that the effects of their actions internationally do not compromise the enjoyment of economic, social and cultural rights" (SKOGLY, 2010, p. 148). According to the CESCR, states "have to respect the enjoyment of the right to health in other countries, and to prevent third parties from violating the right in other countries, if they are able to influence these third parties by way of legal or political means"(CESCR, 2000, Para.39). Likewise, Mesquita, Hunt and Khosla (2010, P.105) emphasize that "states have a legal responsibility to ensure that their laws, policies, and activities support, and do not obstruct, the enjoyment of the right to health in other countries". 
Therefore, not only should the extra-territorial obligations consist of states refraining from taking action that might violate human rights during IAC initiatives, but also it requires that states be active while promoting IAC. In this way, the CESCR stresses that

States parties have a joint and individual responsibility, in accordance with the Charter of the United Nations and relevant resolutions of the United Nations General Assembly and of the World Health Assembly, to cooperate in providing disaster relief and humanitarian assistance in times of emergency, including assistance to refugees and internally displaced persons. Each State should contribute to this task to the maximum of its capacities. Priority in the provision of international medical aid, distribution and management of resources, such as safe and potable water, food and medical supplies, and financial aid should be given to the most vulnerable or marginalized groups of the population. Moreover, given that some diseases are easily transmissible beyond the frontiers of a State, the international community has a collective responsibility to address this problem. The economically developed States parties have a special responsibility and interest to assist the poorer developing States in this regard (CESCR, 2000, Para.40).

In other words, from the statement above, it seems that states' extraterritorial obligations become even clearer when there is the need to provide IAC during humanitarian crisis. In addition, it is during and after natural disasters, armed conflicts and other humanitarian situations when IAC in health ought to be more available. Also in General Comment 14, the CESCR has attempted to draw some elements for prioritisation to IAC in health, in consonance with the right to health core obligations ${ }^{10}$. Therefore, priority should be given to the provision of medical aid, resources and supplies as well as safe and potable water and food. Special attention should be also given to prevent and treat transmissible diseases.

On the other hand, the acknowledgement of extra-territorial obligations gives rise to further concerns. Skogly (2006, P.71), for instance, questions whether the states' extra-territorial human rights obligations clash with the sovereignty and non-intervention principles. She also asks what would be the implications of extraterritorial obligations for multi-lateral and bilateral relations. Both questions are complex and will not be addressed in this study.

10 “Accordingly, in the Committee's view, these core obligations include at least the following: (a) To ensure the right of access to health facilities, goods and services on a non-discriminatory basis, especially for vulnerable or marginalized groups; (b) To ensure access to the minimum essential food which is nutritionally adequate and safe, to ensure freedom from hunger to everyone; (c) To ensure access to basic shelter, housing and sanitation, and an adequate supply of safe and potable water; (d) To provide essential drugs, as from time to time defined under the WHO Action Programme on Essential Drugs; (e) To ensure equitable distribution of all health facilities, goods and services" (CESCR, 2000, Para.43). 


\section{Responsibilities to seek and provide IAC}

At this point, a question arises as to whether there is the responsibility to seek and/or to provide IAC in health. Regarding the obligation to seek IAC, whereas ICESCR acknowledges the progressive realisation of economic, social and cultural rights, State Parties also have immediate obligations. They must take steps to ensure the full realisation of the rights to the maximum of its available resources (ICESCR, 1976, Para.2(1)). The lack of resources does not exempt the State Party from its obligations. In this case, financial and technical cooperation should be sought.

It should be noted that some interpretations on human rights treaties and other instruments emphasize the responsibility of developed countries to provide IAC. For instance, the CESCR observes that the resource availability mentioned by the Covenant regards both domestic resources and those available through IAC (CESCR, 1991, Para.13). Similarly, Mesquita, Hunt and Khosla (2010, P.107; 111), recalling the outcome documents of several UN assemblies and high level meetings, reaffirm the key role developed states play on IAC. For instance, the CESCR on its General Comment 3 is of the view that the responsibility on IAC is particularly incumbent upon those States which are in a position to assist others in this regard" (CESCR, 1991, Para.14). Furthermore, in its General Comment 14, the CESCR emphasizes that:

\footnotetext{
it is particularly incumbent on States parties and other actors in a position to assist, to provide "international assistance and cooperation, especially economic and technical" which enable developing countries to fulfil their core and other obligations indicated in paragraphs 43 and 44 above (CESCR, 2000, Para.45).
}

In the Inter-American system, the Protocol of San Salvador stresses that the adoption of necessary measures, including IAC, should be taken "to the extent allowed by their available resources, and taking into account their degree of development" (1992, Art.1). This standard is also supported by soft law. In the context of HIV, for instance, the UN Declaration of Commitment acknowledges the role played by North-South, South-South and Triangular cooperation and reaffirms the commitments of the Cairo Declaration on Population and Development related to IAC. Concerning the obligation to provide IAC, Mesquita, Hunt and Khosla (2010, P.113) reaffirm the difficulty related to the resources availability and the amount that is expected from donors. For instance, the Cairo Declaration on Population \& Development urges developed states to meet the targets of 0.7 per cent of their gross national product (GNP) for IAC with developing countries (Alma-Ata Declaration, 1994, Para.83). 
While the obligation to seek is generally accepted, the obligation to provide is contested by many States ${ }^{11}$. Although treaties and soft law try to assign responsibilities to states according to their capabilities in order to enable the fulfilment of human rights, both responsibilities - to seek and to provide - are still in need of more guidance for their implementation. While the existence of this obligation is supported by the treaties, it requires clearer standards on 'when' and 'how' to seek and to provide IAC.

It seems clear that states should seek IAC when they lack resources to fulfil their core obligations on the right to health. States could for instance, make use of their diplomatic channels, also indicating their needs on their reports to the UN mechanisms (CESCR, 1990, Para.10). In addition, despite of sought IAC, the beneficiary country still needs to ensure that IAC initiatives will be developed in a way in which they might adhere to human rights principles and do not violate human rights.

Similarly, the capability to 'provide' IAC seems to be more complex than the high value of a country's GNP. For instance, the capability to provide technical cooperation should consider, although it should not be limited to, the level of expertise in the field or area that is sought. From this, it could be implied that the obligation to provide IAC does not rely only on developed countries, since developing countries too have an increased expertise in certain areas ${ }^{12}$. That is the case of the South-South cooperation which will be explored in the next chapter. With the same view, in its report on the ICESCR and poverty, CESCR clarified that the ESCR's 'core obligations give rise to national responsibilities for all States and international responsibilities for developed States, as well as others that are "in a position to assist"' (CESCR, 2001, Para.16). Therefore, a state should 'provide' IAC when it is in a position to assist and it is requested to do so.

The next step is to discuss "how" to provide IAC. If one consider other elements than only the GNP, it leads to different agreements, especially to new ways to promote IAC, such as the triangular cooperation where the responsibility to "provide" relies on two parties: one responsible for the knowledge transfer and another who provides the necessary financial resources for the initiative.

11 For instance, Salomon cites the Swedish speech at the meeting of the Task Force on the Right to Development in 2004 where it challenges IAC as a legal obligation and reaffirms that its practice is based in a moral obligation. In Salomon, M.E. 2010. P. 141. Footnote n.108. See also statements made by the United Kingdom, the Czech Republic, Canada, France and Portugal (UN Doc. E/CN.4/2005/52, para.76) and Canada (UN Doc. E/CN.4/2006/47, para. 82).

12 For instance, Cuba, considered a developing country, is well-known by their advanced system on health care; 
Udombana (2000) discusses the obligations of developed states to assist developing states in realizing their economic, social, and cultural rights, concluding that excessive emphasis has been placed on development aid to less developed countries. In fact, for Udombana, more than aid is needed, including the whole broad meaning of the term "international cooperation" (2000, P.783). Indeed, in the balance of interests to provide IAC, states should have the real development of other countries as the ultimate goal. And, if it cannot be the ultimate goal of IAC, states should at least provide effective contributions for the development of other states when they have opportunities to do so. At this point it is also important to discuss 'how' to promote IAC in a way that it does not violate human rights or provoke more dependency from countries that seek IAC to those who offer and provide it. Those issues will be further addressed in the following sections.

\section{Obligations to respect, protect and fulfil}

There is a broad consensus that economic, social and cultural rights entitle three types of obligations - to respect, to protect and to fulfil. The obligation to respect requires that $S$ tates do not interfere, directly or indirectly, with the enjoyment of the right. The obligation to protect requires State parties to prevent third parties from interfering in any way with the enjoyment of the right. Finally, the obligation to fulfil requires that the State facilitates the access to the rights. It also requires legislative measures, national plans and strategies (CESCR, 2000, Paras. 30-33).

Regarding the obligation to respect, Skogly questions the implications in the current context of this obligation in foreign affairs or IAC (SKOGLY, 2006, P.68). According to her, States must refrain from taking actions that may lead to human rights violations in other territories. Following this view, Mesquita, Hunt and Khosla (2010, P.116), emphasising the state's human rights obligation to IAC in health, conclude that the obligation to respect implies that when states engage in IAC, they "must ensure their actions respect the right to health in other countries" (MESQUITA, ET AL, 2010, P.116). Therefore, as a consequence of its extraterritorial responsibilities, if a state's initiative produces a negative effect on people's health, it will incur responsibilities. Skogly also suggests that the classic notion of human rights obligations, in which states must refrain from interference, was replaced by the duty to adopt positive obligations (SKOGLY, 2006, P.57-58). Thus, states must not only refrain from violating human rights, but also take positive actions to ensure their respect. For instance, when engaging on the provision of health goods to other countries, it could be argued that is not enough to refrain from providing expired goods. In this aspect, it could be suggested that states take all steps to guarantee the safety of the goods during transportation and storage, allowing them to be delivered in perfect conditions to the beneficiaries. 
Mesquita, Hunt and Khosla (2010, P.116) also emphasize that under their obligation to protect, states must "protect against third parties undermining the right to health in other countries". For instance, states must be diligent in ensuring that hired companies or transnational corporations comply with labour and environmental standards as well as other human rights responsibilities (SKOGLY, GIBNEY, 2010, P.6).

In the context of IAC to promote development, the obligations to respect and to protect have particular relevance. Supporting this view, Amartya Sen emphasizes that development is a process to expand freedom and human rights are an integral part of it (SEN, 1999, P.18). When development initiatives rather than promote well-being, violate human rights, it cannot be considered development at all.

Skogly also reminds us of a third obligation that concerns the fulfilment of the right to health (SKOGLY, 2006, P.61). In this way, to fulfil is to ensure the realisation of the right to the highest attainable standard of health, including access to health facilities and medicines. It includes the duty to facilitate opportunities for the enjoyment of the right ${ }^{13}$. Regarding IAC in health, Mesquita, Hunt and Khosla (2010, P.116) make the important point that the obligation to fulfil depends on resources availability. Therefore, as in the other two categories of obligations - to respect and to protect ${ }^{14}$ - states must ensure the necessary resources (technical, financial) when engaging on IAC.

It should be noted that the right to health contains some essential elements. While interpreting the right to health, CESCR concluded that there are four interrelated and essential elements concerning health-care facilities, goods, services and programmes: Availability, meaning they have to be available in sufficient quantity; Accessibility, meaning they have to be accessible - physically and economically, with no discrimination and with all the information concerned - to everyone within the jurisdiction of the State party; Acceptability, in that they should be respectful of medical ethics and culturally appropriate, including life-cycle requirements; and Quality, meaning they must also be of good quality, e.g., scientifically approved hospital equipment, safe and potable water, and adequate sanitation (CESCR, 2000, Para.12). The Availability, Accessibility, Acceptability and Quality (AAAQ) elements have a particular importance to IAC, although it also gives rise to some limitations of IAC initiatives.

13 The category of facilitation was introduced by Mr. Asborn Eide in his report on the right to adequate food and to be free from hunger presented to the CESCR on June 1999. In: Skogly, S. 2006, P.61.

14 The three categories of obligations entail positive and negative actions for which the allocation of resources is necessary. 
Therefore, IAC in health should ensure Accessibility and Acceptability, ensuring efforts are developed on a non-discriminatory basis and taking into consideration the beneficiary country's culture. Also, in regards to Quality, it requires that while delivering health care products, for example, states and institutions acting in their name must meet the highest standards - if not from the recipient country, from the state provider of IAC - for safety and benefit of the target population and those who may need to get in contact with all inputs.

Concerning the Availability element, it should be noted that while states must ensure that health-care facilities, goods, services and programmes are available to all those in need, IAC initiatives come to fill the gaps where domestic resources are not sufficient, financially or technically (STOKKE, 1996). A question arises to whether or how in critical gaps, where the lack of facilities, goods or services is high, IAC should take the responsibility for their total fulfilment and, more specifically, which donor or provider states should be called in, considering the sort of IAC that is sought.

At the same time, the availability element seems to give rise to holding states accountable if they fail to comply with the agreements made ${ }^{15}$. An example of this situation is when a state has an agreement to provide another state with an amount of certain antiretroviral drugs within a fixed period but it fails to fulfil this obligation. It could be argued that the provider state has the obligation to promote reparation, including adequate compensation for the eventual loss of lives that the lack of medicines may have caused. On the other hand, if the provider state took all the necessary steps to avoid this consequence but it still occurs, it could also be argued that the provider state did not perpetrate any wrongful acts and, consequently, should not be made responsible for the impact of these actions. Therefore, to comply with the availability requirement is a complex issue on IAC in health. In view of distinguishing the states' obligations towards IAC in health, the next section will attempt to articulate some core principles.

\section{Core principles}

When it comes to IAC in health, Mesquita, Hunt and Khosla stress that IAC "should be directed to give effect to key features of the right to the highest attainable standard of health" (MESQUITA, ET AL, 2010, P.114). Therefore,

15 According to the General Comment n.14 of the CESCR, paragraph 32: "As with all other rights in the Covenant, there is a strong presumption that retrogressive measures taken in relation to the right to health are not permissible. If any deliberately retrogressive measures are taken, the State party has the burden of proving that they have been introduced after the most careful consideration of all alternatives and that they are duly justified by reference to the totality of the rights provided for in the Covenant in the context of the full use of the State party's maximum available resources". Supra. 
the right to health framework offers to IAC in health a range of principles that should guide initiatives, such as non-discrimination, interdependence, participation, transparency, monitoring and accountability, coherence and coordination, which will be covered in the next sections.

\title{
6.1.1. Non-discrimination and equality
}

Non-discrimination and equality are key features on human rights and should be guaranteed in their exercise. Interpreting the right to health, the CESCR Committee considers discrimination any act in the grounds of:

\begin{abstract}
race, colour, sex, language, religion, political or other opinion, national or social origin, property, birth, physical or mental disability, health status (including HIV/AIDS), sexual orientation and civil, political, social or other status which has the intention or effect of nullifying or impairing the equal enjoyment or exercise of the right to health (CESCR, 2000, Para.18).
\end{abstract}

Considering the state's extra-territorial obligations and the obligation to protect, Skogly argues that states should ensure that third parties under their jurisdiction apply the same human rights standards when operating in another country. Otherwise, it would be discriminatory against those residing in another state (SKOGLY, 2006, P.70). Therefore, states must make use of mechanisms to regulate the conduct of third parties operating in other countries and to hold them accountable for their acts.

Regarding the IAC in health, Mesquita, Hunt and Khosla also emphasize that particular attention should be given to vulnerable groups, ensuring that IAC initiatives will not reinforce discrimination or any other human rights violations (MESQUITA, ET AL, 2010, P.116). To ensure both principles are applied, formally and substantively, special attention should be given to "those individuals and groups who have traditionally faced difficulties in exercising this right" (CESCR, 2003, Para.16). Consequently, to comply with its obligations, States must eliminate discrimination formally and substantially, whether it occurs directly or indirectly, through the adoption of legislation, promotion of policies, plans and strategies, administration and resource allocation (CESCR, 2009, Para.10). Moreover, article 32(a) of the Convention on the Rights of Persons with Disabilities establishes, regarding IAC, that the state's obligation to ensure it is "inclusive of and accessible to persons with disabilities".

Limitations may also be faced in the implementation of this principle, particularly during humanitarian crisis when IAC partners lack information on the target population. However, it is possible to overcome those constraints through dialogue with key actors and information gathering. 
It is acknowledged that stigma and discrimination have a serious impact on people who need to have access to prevention, treatment, care and support, specially people living with HIV and most vulnerable groups such as sex workers, men who have sex with men, transgender people, persons who use illicit drugs and inmates. Therefore, IAC in health should not reproduce or reinforce patterns of stigma and discrimination. On the contrary, in compliance with states' human rights obligations, IAC should promote non-discrimination against the most affected groups and fair treatment to everyone who might need health-care.

\subsection{Interdependence}

The interdependent relationship between all human rights has been expressed by several international human rights documents. Taking this view into consideration, Robinson makes the important point that those documents go further when "[ $t$ ]hey assert that these rights must be effectively enjoyed, whether a country is developing or developed, and that a participatory democracy, based on the rule of law, is the only system of government that can ensure the implementation of all rights"(ROBINSON, 2005, P.27). It should be stressed that the right to health is not confined to health care but also entails underlying determinants of health, considering "the conditions in which people are born, grow, live, work and age" (CSDH, 2008, P.1).

Economic, social and cultural rights cannot be guaranteed if civil and political rights are under threat (CESCR, 2000). It requires that the right to health is not viewed in isolation from other human rights. For instance, if a health facility is built through IAC but people cannot easily reach it because of lack of transportation, or if medicines are made available but nutritional support is still needed, or even if people are not free from hunger, the efficacy of those IAC initiatives may be compromised.

However, promoting health initiatives that take into account the human rights interdependence is not an easy task and requires the existence of available information and mechanisms for the integration and coordination of initiatives.

\subsection{Participation}

The right of every citizen to take part in the conduct of public affairs is asserted by article 25(a) of the International Covenant on Civil and Political Rights (1976). Interpreting this provision, the Human Rights Committee clarifies that the conduct of public affairs "covers all aspects of public administration, and the formulation and implementation of policy at international, national, regional and 
local levels" (HRC, 1996, Para.5). CESCR regards participation as a key element of the right to health. In General Comment 14, it emphasizes the need to promote participation "in all health-related decision-making at the community, national and international levels" (CESCR, 2000, Para.11).

Potts argues that "active and informed" participation should be enabled, giving people the opportunity to put issues onto the health agenda at the initial stage (preference revelation), also in the formulation (policy choices), implementation and monitoring and evaluation stages (POTTS, S.D. P.16-17). Supporting this view, in a study on the promotion of health care in developing countries, Gauri concludes that participation is constitutive of good service delivery (GAURI, 2005, P. 79). Therefore, to establish formal mechanisms is essential in order to enable participation. In this case, Hunt also suggests that the establishment of these mechanisms should be guided by an accessible, fair, transparent and continuous process (HUNT, 2008, P.63).

Likewise, Mesquita, Hunt and Khosla stress the duty to promote the participation of the groups affected by IAC initiatives (2010, P. 115). In this view, it is acknowledged that to promote participation of the affected groups may result in ownership for initiatives implemented and their results. Some initiatives have demonstrated that the lack of participation resulted in "inappropriate, unwanted or unnecessary projects" (UNDP, 2007, P.9). It is also important to mention that to promote participation during the context of armed conflicts and other humanitarian situations can be even more complex, since issues of legitimacy may arise during critical conditions.

While the importance of the participation of the population affected by the initiative develops consensus among donors, the effective participation of government representatives of the beneficiary country has been less addressed in the design and implementation of official IAC initiatives. Two situations commonly arise from IAC: official IAC being negotiated and implemented directly with non-governmental organisations without acknowledging the government of the beneficiary country and the launching of 'top-down' initiatives that ignore the complexity of the beneficiary country. These practices, which have been traditionally employed for the past sixty years, are nowadays being discussed with criticism, calling for a different approach to IAC. Similar to the participation of the populations affected by the initiatives, it is important to note that the effective participation of states is a key issue to the success of IAC. In addition to the ownership and acceptability of the initiatives, the involvement of states in IAC may also contribute to providing coherence between national policies and IAC coordination. This point will be further addressed in section 6.5. 


\subsection{Transparency}

Interpreting the right to health addressed by article 12 of ICESCR, CESCR in its General Comment 14, CESCR also regards transparency as an important element (CESCR, 2000, Paras. 45; 55). CESCR does not address in detail how the principle of transparency should be read with reference to the right to health. However, reading it in conjunction with article 19 of the ICCPR, this principle should be regarded as the obligation to provide relevant information that might have implications to the exercise of the right to health. Article 19 of ICCPR in paragraph 2 states as follows:

Everyone shall have the right to freedom of expression; this right shall include freedom to seek, receive and impart information and ideas of all kinds, regardless of frontiers, either orally, in writing or in print, in the form of art, or through any other media of his choice.

At the recent General Comment 34 on freedoms of opinion and expression, the Human Rights Committee emphasizes that the right of access to information includes records held by a public body, regardless of the form in which the information is stored, its source and the date of production"(HRC, 2011, Para.18).

In what concerns the right to health, Hunt notes that "[i]t is not possible to properly understand and meaningfully evaluate access to medicines policies and practices without the disclosure of key information" (HUNT, 2008, P.18). The author also argues that:

There is a presumption in favour of disclosure, which may be rebutted on limited grounds (Guideline 6). Common sense confirms that the principle of transparency not only requires that information be made publicly available, it also requires the information be made publicly available in a form that is accessible, manageable and useful (Guideline 7). An independent, trusted and informal body should be established to consider any disputes that may arise about whether or not a particular piece of information relating to access to medicines should be disclosed (Guideline 8). This body should also provide guidance on the legitimate grounds of non-disclosure. While Guidelines 6-8 have general application to access to medicines, other Guidelines apply the cardinal principle of transparency in specific contexts, such as public policy influence, advocacy and lobbying (Guidelines 17-19) "(HUNT, 2008, P.18).

Andersson (2008, P.134) also makes an important point about the need of transparent processes. His approach to transparency suggests that it serves two purposes: to increase the awareness of decision-makers and to give the public insight and influence. 
Translating these concepts and elements into IAC in health, it means that all partners have to clearly state the necessary information, at least, between themselves, including the beneficiary country and groups affected. People and institutions have the right to know everything that may concern their and their people's health and well-being. Therefore, it should include information about what, how, how much and to whom the IAC is being designed and implemented.

\subsection{Monitoring and Accountability}

Monitoring and accountability are key issues for human rights. They require knowledge about the situation to be faced and the establishment of clear objectives and outcomes. In light of this, Robinson suggests that promoting accountability in regard to human rights obligations may assist decision-making processes in order to avoid undesirable or discriminatory outcomes (ROBINSON, 2005, P.35). Monitoring and accountability are understood as part of the implementation of the right to health, requiring the adoption of a framework, appropriate indicators, benchmarks and remedies in case of non-fulfilment (CESCR, 2000, Paras.56-59). Regarding accountability as a central feature of human rights, Hunt and Leader suggest that it should also be promoted by States through councils, public hearings and other mechanisms (HUNT, LEADER, 2010). Furthermore, among several mechanisms, judicial proceedings can also help to turn States accountable about their obligations related to the right to health.

Moreover, Potts suggests that the engagement on monitoring and accountability requires a prospective and retrospective approach (POTTS, 2008, P.13). It must look forward and back to all the IAC phases in order to ensure the compliance with the agreed standards. Furthermore, considering the state's obligations to respect, protect and fulfil, the Maastricht Guidelines ${ }^{16}$ draws attention to the obligation's elements of conduct and result. While the obligation of conduct "requires the adoption and implementation of a plan of action (...) the obligation of result requires States to achieve specific targets to satisfy a detailed substantive standard" ${ }^{\prime 7}$. Moreover, in the context of IAC Skogly and Gibney argue that other actors should be assessed in addition to domestic governments, including foreign states. Therefore, assessing the steps taken by all the partners of the initiative as well the results and impacts in the original context gives rise to informed decisions and, when necessary, the provision of remedies.

16 Maastricht Guidelines on Violations of Economic, Social and Cultural Rights, Maastricht, January 22-26, 1997.

17 Ibid at Para.7. 
In the context of HIV, since 2001 the UNGASS Declaration has been a relevant starting point to measure progress towards the fulfilment of HIV-related commitments. Every two years states shall report their progress, guided by core indicators. However, it does not recognise the commitments established through "development assistance or aid programmes" as part of the monitoring and accountability process (UNAIDS, 2009). Among its indicators, the only mention of IAC relates to the financing resources received from international partners (UNAIDS, 2009, P.85-88).

Moreover, the adoption of the Paris Declaration on Aid Effectiveness in 2005 can be regarded as an effort towards monitoring and accountability in IAC (OECD, 2005). It sets five main commitments to guide it: ownership, alignment, harmonisation, results, and mutual accountability. Also, in 2008, the UNAIDS' report on the implementation of the "Three Ones" and Global Task Team recommendations $(G T T)^{18}$, within the context of international efforts towards aid effectiveness and UN Reform, argues that ensuring a sole monitoring and evaluation system in which all international partners might participate had proved to be difficult (UNAIDS, 2008). Therefore, despite the different efforts, there is still a long way to ensure that countries and institutions comply with monitoring and accountability requirements. The establishment of an independent mechanism to fulfil this task and make countries and institutions accountable would be something to look forward to.

\subsection{Coherence and Coordination}

Mesquita, Hunt and Khosla emphasize the need for the consistent and coherent application of the international right to health to the national and international policy-making process, with its integration into the several state's policies, programmes and practices related to health (MESQUITA, ET AL, 2010, P. 116). For instance, in 2005, the World Health Report demonstrated that maternal, newborn and child health were strongly linked, urging the integration with regard to programming and resource mobilisation (WHO, 2005, P.10). As a result, a global initiative called "The Partnership for Maternal, Newborn \& Child Health" was launched in the same year. To ensure children's health, the initiative urges countries and donors to strengthen joint strategies. Furthermore, it calls for integration of children's health strategies into nationwide health plans.

The efforts, nonetheless, must be coordinated. CESCR, in its General Comment n.14 on the right to health, concludes that "coordinated efforts (...) should be maintained to enhance the interaction among all the actors concerned, including the various components of civil society"(CESCR, 2000, Para. 64). Coordination between the different actors involved in IAC in health can bring the benefit to avoid

18 This Task Team applies the Paris Principles to the context of HIV. 
fragmentation and duplication of aid initiatives. The coordination of IAC initiatives also gives rise to important implications to states' responsibilities towards IAC. In other words, it means that coordination has the potential to identify the gaps where IAC is needed and fulfil them through, for instance, bilateral or multilateral agreements. Consequently, the coordination of IAC in health should consider the establishment of coordinating boards or committees with the important task of coordinating the different needs, initiatives and actors, by making use of mechanisms to promote IAC human rights' guiding principles such as participation, transparency and monitoring and accountability.

\section{Conclusions}

The international human rights treaties, jurisprudence and soft law seem to provide enough basis for states obligations towards IAC related to the right to health. The provision of medical aid, resources and supplies as well as safe and potable water and food are, then, regarded as core obligations of IAC in health. The fact that human rights obligations are not confined to a state's own territory provides that while engaging in IAC states should also respect, protect and fulfil the right to health in other countries. Although some states ignore the obligation to provide IAC, no doubt seems to arise as to considering states' obligations to provide IAC during humanitarian crisis. Therefore, to seek and to provide IAC in health is an obligation on states that should be honoured.

In view of designing and implementing IAC, some guiding principles still need to be drawn. For this purpose, it should be noted that IAC in health should ensure the key features of the right to health. In other words, while engaging in IAC in health, states should ensure that the principles of non-discrimination and equality, interdependence, participation, transparency, monitoring and accountability, coherence and coordination are in the core of their initiatives. There is a gap in the literature in regard of other principles that might be relevant to IAC in health. For instance, IAC in health should also consider the sustainability of the initiatives that are being promoted. Thus, it could be argued that, in order to promote technical cooperation in health, countries should be encouraged to transfer technology and knowledge, without generating dependency from IAC initiatives, as it will be explored in the next chapters. Although this is a non-exhaustive list, it is not clear whether these broadly accepted principles are relevant to South-South cooperation.

In addition, the very implementation of these principles is found to be a complex issue. In fact, the traditional way to cooperate - the North-South IAC, promoted from developed to developing country - has been challenged by an increasing trend that locates developing countries as providers of cooperation. This change to the IAC scene may bring new perspectives on the guiding principles detailed above. 


\section{Bibliography}

ACHPR. African Commission of Human and Peoples Rights. Democratic Republic of the Congo v Burundi, Rwanda and Uganda (2004) AHRLR 19. 2003.

ANDERSSON, K. Transparency and Accountability in Science and Politics: The Awareness Principle. Palgrave Macmillan, 2008.

AXELROD, R. and Keohane, R. Achieving Cooperation Under Anarchy: strategies and institutions. World Politics, Vol. 38, No. 1. (Oct., 1985), pp. 226-254.

BANKOVIC V. BELGIUM ET AL. 11 BHRC 435. 2001.

BRAZIL. UNGASS - Brazilian Response 2005-2007. Country Progress Report. Available at: http://data. unaids.org/pub/Report/2008/brazil_2008_country_progress_report_en.pdf

UNGASS - Brazilian Response 2008-2009. Country Progress Report. Available at: http:// www.unaids.org/en/dataanalysis/monitoringcountryprogress/2010progressreportssubmittedbycountries/ brazil_2010_country_progress_report_en.pdf

CESCR. General Comment 2. International technical assistance measures (art. 22). 02 February 1990.

General Comment 3. The nature of States parties' obligations (art.2 (1)). Contained in document E/1991/23. 1991.

General Comment 14. The right to the highest attainable standard of health (article 12 of the International Covenant on Economic, Social and Cultural Rights). E/C.12/2000/4. 2000.

General Comment 20. Non-Discrimination in Economic, Social and Cultural Rights (art.2, para.2). E/C.12/GC/20. 2009.

Poverty and the International Covenant on Economic, Social and Cultural Rights. 05/10/2001. E/C.12/2001/10. (Other Treaty-Related Document) 10 May 2001.

ECHR. European Court of Human Rights. Loizidou v. Turkey (Appl.n¹5318/89), Judgement 18 December 1996 (Merits).

GAURI, V. Social Rights and Economics: Claims to Health Care and Education in Developing Countries. In: ALSTON, P.; ROBINSON, M. Human Rights and Development towards Mutual Reinforcement. Oxford University Press, 2005. P.65-83.

GEGP. Global Economic Governance Programme. University of Oxford. Setting a Developing Country Agenda for Global Health. Preliminary Report of a High-Level Working Group. (May 2008).

GOMEZ ISA, F. Transnational Obligations in the Field of Economic, Social and Cultural Rights. Revista Electronica de Estudios Internacionales. N. ${ }^{\circ} 18$. Available at: http://www.reei.org.

HRC. General Comment 25. The right to participate in public affairs, voting rights and the right of equal access to public service (Art. 25) : . 07/12/1996. CCPR/C/21/Rev.1/Add.7, General Comment No. 25. (General Comments).

HRC. General Comment 31. The Nature of General Legal Obligations Imposed on States Parties to the Covenant (Article 2). UN Doc. CCPR/C/21/Rev.1/Add.13. 2004.

HUNT, Paul. Human Rights Guidelines for Pharmaceutical Companies in relation to Access to Medicines. Report to the General Assembly of the UN Special Rapporteur on the right to the highest attainable standard of health. A/63/263. 11 August 2008. Annex. 
Report of the Special Rapporteur on the right of everyone to the enjoyment of the highest attainable standard of physical and mental health. UN Doc. A/HRC/7/11, 31 January 2008.

IBSA. India-Brazil-South Africa Dialogue Forum. Fourth Summit of Heads of State/Government. Brasilia Declaration. 15 April 2010. Available at: http://www.itamaraty.gov.br/temas-mais-informacoes/ saiba-mais-ibas/documentos-emitidos-pelos-chefes-de-estado-e-de/4th-ibsa-summit-declaration.

IACHR. Inter-American-American Commission of Human Rights. Coard et.al. v. United States. Case 10.951. Report n.109/99. 29 September 1999. Available at: http://www1.umn.edu/humanrts/cases/us109-99.html.

MAASTRICHT GUIDELINES ON VIOLATIONS OF ECONOMIC, SOCIAL AND CULTURAL RIGHTS. Maastricht, January 22-26, 1997.

MESQUITA, J. Bueno de. International Covenant on Economic, Social and Cultural Rights: Obligations of International Assistance and Cooperation. 2002.

MESQUITA, Judith; HUNT, Paul and KHOSLA, Rajat. The Human Rights Responsibility of International Assistance and Cooperation in Health. In: SKOGLY, S.; GIBNEY, M. (eds.) Universal Human Rights and Extraterritorial Obligations. University of Pennsylvania Press, 2010. P. 104-129.

OECD. Paris Declaration on Aid Effectiveness. Ownership, Harmonisation, Alignment, Results and Mutual Accountability. 2005. Available at: http://www.oecd.org/dataoecd/11/41/34428351.pdf

OSLO DECLARATION “Foreign Policy and Global Health Initiative”. UN Res.63/33. 2007.

POTTS, H. Accountability and the Right to the Highest Attainable Standard of Health. Available at: http://www.essex.ac.uk/human_rights_centre/research/rth/docs/HRC_Accountability_Mar08.pdf (2008).

Participation and the right to the highest attainable standard of health. Available at: http:// www.essex.ac.uk/human_rights_centre/research/rth/docs/Participation.pdf

ROBINSON, M. What Rights Can Add to Good Development Practice. In: ALSTON, P.; ROBINSON, M. Human Rights and Development towards Mutual Reinforcement. Oxford University Press, 2005. P.2541 .

SALOMON, M.E. International Human Rights Obligations in Context: Structural Obstacles and the Demands of Global Justice. In: BARD, A.; ANDREASSEN; MARKS, Stephen P. (eds.) Development as a Human Right: Legal, Political and Economic Dimensions. Antwerp: Intersentia, 2010. P. 121-147.

SEN, Amartya. Development as Freedom. Oxford University Press, 1999.

Human Rights and Development. In: ANDREASSEN; MARKS, Stephen P. (eds.) Development as a Human Right: Legal, Political and Economic Dimensions (2nd ed.), Antwerp: Intersentia, 2010. P. 3-12.

SKOGLY, S. Beyond National Borders: States' Human Rights Obligations in International Cooperation. 2006.

SKOGLY, S.; GIBNEY, M. Introduction. In: SKOGLY, S.; GIBNEY, M. (eds.). Universal Human Rights and Extraterritorial Obligations. University of Pennsylvania Press, 2010. P. 1-9.

STOKKE, O. Foreign Aid Towards the Year 2000: Experiences and Challenges. London: Frank Cass, 1996.

TORRONTEGUY, M.A. The role of international cooperation in establishing human rights: Brazil, the Portuguese-speaking African Countries and the right to health. RECIIS - R. Eletr. de Com. Inf. Inov. Saúde. Rio de Janeiro, v.4, n.1, p.53-61, Mar., 2010. 
UDOMBANA, N.J. The Third World and the Right to Development: Agenda for the Next Millennium. Human Rights Quarterly, Vol. 22, 2000.

UNAIDS. Three one key principles. 2004. Available at: http://www.unaids.org/en/media/unaids/ contentassets/dataimport/una-docs/three-ones_keyprinciples_en.pdf

Enhancing results by applying the Paris Declaration at sector level: Progress update and Lessons Learnt from Aid Effectiveness in AIDS Responses. April 2008. Available at: http://www.unaids. org/en/media/unaids/contentassets/dataimport/pub/report/2008/20081023_accraprogressupdate_en.pdf

UNDP. Regional Initiative on Indigenous Peoples' Rights and Development and Cordillera Indigenous Peoples' Legal Centre. Indigenous Peoples and the Human Rights-Based Approach to Development: Engaging in Dialogue. 2007. Available at: http://regionalcentrebangkok.undp.or.th/practices/governance/documents/ Indigenous_Peoples_HRBA_Development-2006.pdf

US. Correspondence between the US Embassy in Maputo and the US government. 05MAPUTO725. REF: A. PRAIA 268 B. STATE 102443. Available at: http://apublica.org/2011/06/05maputo725/

\section{International instruments}

AFRICAN CHARTER. African Charter on Human and Peoples' Rights. Adopted 27 June 1981, entered into force 21 October 1986) (1982) 21 ILM 58.

ALMA-ATA DECLARATION. Report of the International Conference on Population and Development. Cairo, 5-13 September 1994 (United Nations publication, Sales No. E.95.XIII.18), chap. I, resolution 1, annex, chaps. VII and VIII.

COPENHAGEN DECLARATION ON SOCIAL DEVELOPMENT AND PROGRAMME OF ACTION OF THE WORLD SUMMIT FOR SOCIAL DEVELOPMENT. Adopted 12 Mar. 1995, at Annex I, ๆ 23, U.N. Doc. A/CONF. 166/9 (1995), available at gopher://gopher.undp.org:70/00/unconfs/wssd/summit/ off $/ \mathrm{a}-9$. .en

DECLARATION ON THE RIGHT TO DEVELOPMENT. Adopted by the General Assembly in its resolution 41/128 of 4 December 1986.

INTERNATIONAL COVENANT ON CIVIL AND POLITICAL RIGHTS. 999 UNTS 171 (ICCPR). Adopted 16 December 1966, entered into force 23 March 1976.

ICESCR. International Covenant on Economic, Social and Cultural Rights. Adopted by the UN General Assembly in 1966, entry into force 3 January 1976.

INTERNATIONAL CONVENTION FOR THE PROTECTION OF ALL PERSONS FROM ENFORCED DISAPPEARANCE. Adopted on 20 December 2006 during the sixty-first session of the General Assembly by resolution A/RES/61/177. Entered into force on 23 December 2010.

PROTOCOL OF SAN SALVADOR. Additional Protocol to the American Convention on Human Rights in the Area of Economic, Social and Cultural Rights (entered into force 16 November 1999) OAS Treaty Series No 69 (1988) reprinted in Basic Documents Pertaining to Human Rights in the Inter-American System OEA/ Ser L V/II.82 Doc 6 Rev 1 at 67 (1992).

UN. United Nations Millennium Declaration. Resolution adopted by the General Assembly. A/55/L.2. 2000. UNITED NATIONS, UN (1978) Buenos Aires Plan of Action for Promoting and Implementing Technical Co-operation among Developing Countries 1978. Documentation. UN. Resolution adopted at General Assembly's 33rd Session (A/RES/33/134).

UNITED NATIONS CONVENTION ON THE RIGHTS OF PERSONS WITH DISABILITIES. Adopted on 13 December 2006 during the sixty-first session of the General Assembly by resolution A/RES/61/106. 
UNITED NATIONS CONVENTION ON THE RIGHTS OF THE CHILD (1989). Adopted by General Assembly resolution 44/25 of 20 November 1989. Entry into force 2 September 1990.

UNIVERSAL DECLARATION OF HUMAN RIGHTS. UNGA Res 217 A(III) (UDHR). Adopted 10 December 1948.

UNGASS. United Nations General Assembly. Special Session on HIV/AIDS. 25 - 27 JUNE 2001. Available at: http://data.unaids.org/publications/irc-pub03/aidsdeclaration_en.pdf

VIENNA DECLARATION AND PROGRAMME OF ACTION. UN Doc. A/CONF.157/23. Adopted by the General Assembly in 12 July 1993.

\section{Angela Pires Terto}

angelapiresp@gmail.com

Master in International Human Rights and Humanitarian Law, University of Essex, UK, Doutoranda no Programa de Pós-Graduação em Desenvolvimento, Sociedade e Cooperação Internacional do Centro de Estudos Avançados Multidisciplinares da Universidade de Brasília, Bolsista CAPES. 